\title{
Art Education Based on Joyful Learning Method and Information Communication Technology at Insan Mulia School of Nature Surabaya
}

\author{
Idealita Ismanto \\ Pendidikan Seni Budaya, Pascasarjana Universitas Negeri Surabaya, Gedung K9 Kampus UNESA \\ Ketintang, Surabaya, 60231, Indonesia \\ idealita.dea@gmail.com
}

This article discusses joyful learning method in Insan Mulia Surabaya School of Nature and describes ICTbased art education (Information and Communication Technology) at Insan Mulia School of Nature Surabaya. This research uses qualitative approach and descriptive research type. Data collection procedure is done by observation and interview method. Data analysis activities started from the data collection stage, the reduction phase, the data presentation stage, and the conclusion drawing stage. Data validation checks are performed with source triangulation, and method triangulation. The results of the study showed that: (1) Bina Insan Mulia's school education has a learning model of joyful learning (2) ICT-based arts education (Information and Communication Technology) to make student learning activities more interesting and not monotonous.

Keywords: art education, ICT, School of Nature

\section{Pendidikan Seni Berbasis Metode Joyful Learning dan ICT (Information and Communication Technology) di Sekolah Alam Insan Mulia Surabaya}

Artikel ini membahas tentang metode pedidikan joyful learning di Sekolah Alam Insan Mulia Surabaya dan mendeskripsikan pendidikan seni berbasis ICT (Information and Communication Technology) di Sekolah Alam Insan Mulia Surabaya. Penelitian ini menggunakan pendekatan kualitatif dan jenis penelitian deskriptif. Prosedur pengumpulan data dilakukan dengan metode observasi dan wawancara. Kegiatan analisis data dimulai dari tahap pengumpulan data, tahap reduksi, tahap penyajian data, serta tahap penarikan kesimpulan. Pengecekan keabsahan data dilakukan dengan triangulasi sumber, dan triangulasi metode. Hasil penelitian menunjukkan bahwa: (1) pendidikan sekolah alam Bina Insan Mulia memiliki model pembelajaran joyful learning (2) pendidikan seni berbasis ICT (Information and Communication Technology) membuat kegiatan belajar siswa lebih menarik dan tidak monoton.

Kata Kunci : pendidikan seni, ICT, Sekolah Alam.

Peer review : 9 - 23 Agust 2018, Accepted : 3 September 2018 


\section{INTRODUCTION}

Pedagogic or educational science is the one who investigates, ponders about the symptoms of educational acts. The term is derived from the word "pedagogia" (Greek) which means association with children. In a simple and general sense the meaning of education as a human effort to cultivate and develop the innate potentials both physical and spiritual in accordance with the values that exist in society and culture. The efforts undertaken to instill these values and norms and pass it on to the next generation to be developed in life and that occurs in an educational process. Therefore, any civilization of society, in which it takes place and there is a process of education as a human effort to preserve his life (Ihsan, 2008: 2).

Departure from a concern over the condition of our nation, which has not been completely separated from the cycle of crisis, value crisis or in terminology F. Capra 'existential crisis', 'multicultural crisis' according to Habermas. This value crisis is reflected by the spread of various events and acts of violence.

The signification of art education for students is to cultivate the nature of feelings and provide a psychic foundation whether terrorist or practical in order to express feelings through the medium of art. Because, logical intelligence alone is not enough to educate children to have a mature soul as individuals and as social beings.

Art education that focuses more on taste is an independent and psychomotor psychical nature manifestation to form a whole personality. In other words, that by forming a child with mature personality is not enough with intelligence and intelligence in the field of logic alone as a cognitive product, but must be balanced with emotional intelligence, in the sense of panai using affection through the power of creativity and imagination that is processed into aesthetic artwork. The point is that students are able to control their feelings to lead to the development of mature individuals, along with it intelligently intellectually to face complex social reality (Jazuli, 2008, 2).

"Art" is a way of understanding through individual artistic experiences to recognize oneself and others. Art is also something natural in human life. Art is the intrinsic aspect of human life. History has shown that humans have decorated their lives with ornaments, pitched voices, dramatic stories and various forms of celestial dance. The form of such artwork is very important for life.

The education system in Indonesia has recently be-

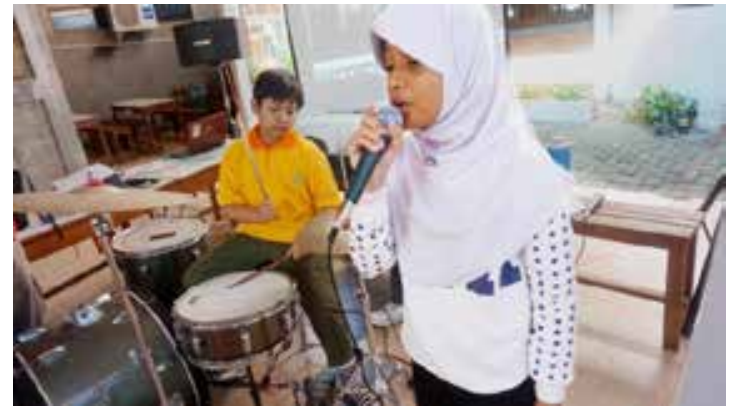

Figure 1. student sing with their classmate (private documentation)

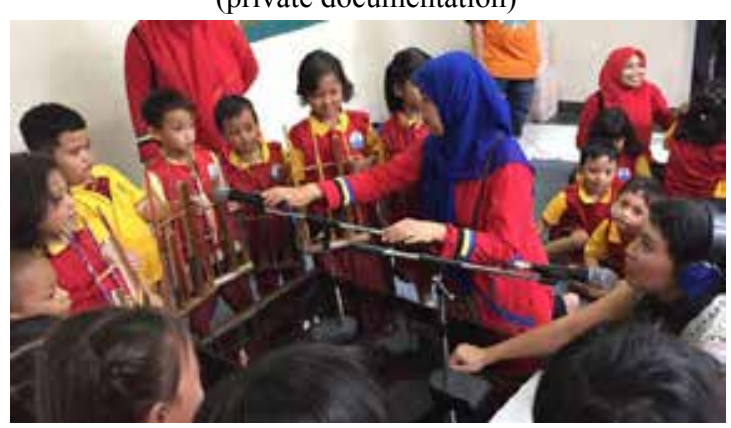

Figure 2. students play angklung with their teacher in outdoor activity. (private documentation)

come a debate in society. Starting from an increase in the standard of graduation that resulted in the number of students who did not pass, the curriculum continues to change to the human resources that many unemployed. This makes the education system of Indonesia needs to be reviewed. Why many students who do not graduate are outstanding students while currently many school graduates are not able to apply what they learn. Not to mention the change of curriculum that confuses teachers and students to determine what system is suitable to apply.

One form of the current education system began to develop in Indonesia is a natural school education. The school system is different from the formal school. The curriculum applied in this school is prepared by the teaching staff to suit the students' abilities. This education system combines theory and its application.

A natural school is a school that is built for educational development efforts conducted in the open to know the learning of all living things in nature directly. In contrast to schools in general using classroom systems, students at natural schools are free to spend more time interacting in the open so as to form direct learning on experiential materials and learning.

The Insan Mulia School of Nature uses a national curriculum enriched international curriculum. The school applied the learning model joyful learning, which is learning in the atmosphere of play. Students are not confined to classroom learning, but also ex- 


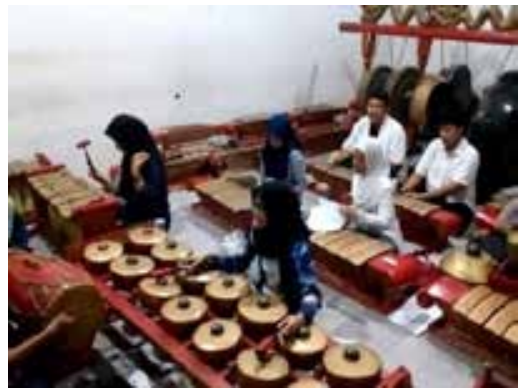

Figure 3. student play gamelan with their classmate in indoor activity (private documentation)

plore the outdoors. All the subject matter is related to daily life according to the child's thinking level. To learn about growth, for example. Students will be invited to examine the sapodilla fruit in the hydroponic garden, observe the fish in the pond, observe the newly hatched chickens, and even plant seeds in the school garden.

But whether the noble Insan school of nature is a natural school that the application of learning is good enough in educational institutions, with learning model Information Communicatiaon Technologies (ICT). Therefore, it is necessary to do research and problem solving in response to my curiosity about the application of Information Communication Technologies (ICT) learning in Sekolah Alam Bina Insan Mulia Surabaya

\section{METHOD}

The research aims to obtain data on ICT-based Art Education (Information and Communication Technology) at Alam Insan Mulia School Surabaya. The method used is qualitative descriptive. Qualitative methods are used to obtain in-depth data, a data that contains meaning. Meaning is the actual data, the exact data and is a value behind the visible data (Afiffudin and Saebani, 2012: 59). The meaning that strives to be shown in this research is to know ICT-based art education in Alam Insan Mulia Surabaya school. The type of research used is descriptive, ie to describe the method of learning ICT (Information and Communication Technology).

\section{RESULT}

\section{Joyful Learning Learning Model on art education} at Sekolah Alam Insan Mulia.

Alam Insan Mulia School was built in early 2000 by the leader of Insan Mulia School of Nature, Drs. H. Moh Sulthon Amien. MM based on religion and international vision in Surabaya. Insan Mulia Nature School as a laboratory of life has a vision of becoming the best educational institutions that gave birth to generations and Muslim leaders who have noble and world-quality. Therefore, the learning model is made as comfortable and as real as possible so that students are happy and welcome to follow the learning process and all the school activities.

The Insan Mulia School of Nature is particularly interested in fun learning methods. Pupils also learn from nature by loving and protecting the environment. Sekolah Alam Insan Mulia also trains students' entrepreneurs to become strong, independent and successful entrepreneurs.

However, entrepreneur spirit will not be embedded properly if it does not have good building character, therefore, Sekolah Alam Insan

Mulia plays the foundation of character with noble character. Students have entered into the global era, Indonesian children must be able to compete with other countries. The Insan Mulia School of Nature collaborates with overseas schools. Vision of Insan Mulia Nature School is Religious, Honesty, Leadership, Joyful Learning, Emphaty, Entrepreneurship.

The mission of Alam Insan Mulia School is to create a fun, creative, and applicative learning environment by observing the students' development and potential, fostering appreciation and practice toward Islamic values and culture, making the generation with emotional maturity, independent personality, honest, responsible, as well as care for the environment and fellow and cultivate the ability to compete in the global era.

The concept of education used Insan Mulia School of Nature has five concepts, among others, the first school that fosters Islamic values. As a religious-based educational institution of Islamic religious education is taught in a contextual and integrative with other learning eyes because the values aqidah akhlak. Presented in the context of the needs and life of the students finds it easy to harmonize the relationship of revelation to know knowledge, so that behavior changes to the better direction and also guide the students in performing their functions as Abdullah (Khalifatullah Fil Ardh) Natural).

Second, Insan Mulia School of Nature has a school concept that is not burdensome. The Insan Mulia School of Nature is designed as a school that does not burden students. A school that makes the child so cheerful when learning. They feel happy and feel at home in their school.

Third, Insan Mulia School of Nature has a school concept as an apprenticeship process. Historically, at first school was none other than a place of apprentice- 
ship. Apprenticeship in a traditional society is to learn a person's skill, a process of working while learning. Holding on to the nature of the apprenticeship, the subject matter at SAIM does not depart.

Fourth, the concept of Insan Mulia School of Nature is another school that fosters diversity. In principle, Insan Mulia School of Nature upholds diversity. Each student is different, then each uniqueness should be appreciated. This form of appreciation is a way of treating them and the application of learning methods that attempt to accommodate the differences. Students develop according to their basic potential, the rest he can be anything that suits his wishes. It is up to him to be like Hamka, Chairul Tanjung, Steve Job, Habibie or Siti Nurhalizah, the important School of Nature Insan Mulia prepare basicnya.

Fifth, the concept of Insan Mulia School of Nature sharpening skills, processing information and communicating it. The Insan Mulia School of Nature is not tempted to cram much lesson material for the students. In this school the child is invited to learn to capture the information and then process it with two or more schemata, becoming useful for his practical needs. The ability to synthesize two schemata and cultivate it is urgent. Not much benefit can be taken if a child is given a stack of knowledge if he or she is not trained to look for links or synthesize them. The child is no more than just a "walking dictionary", knowing the definition of abstract formulas. In addition to the ability to process information, students of Alam Insan Mulia School are equipped with the ability to convey the information received through the refraction of presentation and public speaking. Students are given public speaking training.

Alam Insan Mulia Surabaya primary school "SAIM", is a school concerned with the unique potential and psychological development of its students. Schools are trying to answer the parents' complaints about why children are reluctant to go to school, lazy to learn, and not eager to do the work. SAIM primary school makes a new breakthrough in the world of education by applying a fun learning model with a comfortable environment.

SAIM primary school designed the school to be a child-friendly learning ground, so the children feel at home in school. Unlimited learning in the classroom; gazebos, mini zoos, fields, mosques, laboratories, libraries, and cafeterias are used as educative venues. Teachers, students, and parents become partners in learning in every learning process. The concept of integrated education learning, thematic teaching, and joyful learning deliver activities that jumpstart the potential of students with various life skills learning process.

The curriculum of SAIM still refers to the national curriculum, developed in a variety of learning innovations are fun and up to date. All subjects are presented in an integrated way in the concrete and applicative theme of everyday life.

Teaching and learning activities conducted at Sekolah Alam Insan Mulia Surabaya is each class with a maximum number of 28 students, guided by 2 teachers. Teachers act as facilitators, counselors, and parents who understand each student's uniqueness. In addition to classroom teachers, some teachers who collaborate with students in the learning process are students; art teacher, music, reading, and arabic language. SAIM primary school tries to activate the learning system "thoroughly" in school. This can minimize the load at home (no homework concept). Evaluation model of student development in descriptive analysis in the realm; cognitive, affective, and psychomotor are communicated to parents with positive language.

The concept of learning by Sekolah Alam Insan Mulia Surabaya is thematic to be part of a whole process of understanding and centered on student interests. All learning materials are linked to the lives facing children today and later, through an approach tailored to the child's psychological development.

Integrated learning presents students' sensitivity to problem solving from various facets of science; spiritual / akidah, social, and scientific. Project-based learning is the hallmark of SAIM Primary School to build the character of cooperation, self-management, courage to express ideas, and creativity of children. Extracurricular activities are conducted to identify students' talents, abilities, and self-development.

Insan Mulia Nature School has a school concept that is not burdensome. The Insan Mulia School of Nature is designed as a school that does not burden students. A sekolalah that makes the child so cheerful when learning. They feel happy and feel at home in their school. Therefore, in general, the practice of education using three concepts pemajarang namely integrated learning, joyful learning, and cooperatel earning.

According to Paulo Fraire, Joyfull learning is a learning in which there is no more pressure, either physical or psychological pressure. Because, whatever pressure his name will only dwarf the minds of students, while any freedom of his form will be able to encourage the creation of a conducive learning climate (learning climate). 
So joyfull learning is the approach used by teachers in this case is the teacher to make students more able to receive the material delivered which is due to a pleasant atmosphere and without tension in creating a sense of pleasure. The creation of a sense of joy in relation to the condition of the soul is not a process of learning it creates a noisy atmosphere. And fun or exciting in classroom learning does not mean creating a melee atmosphere in classroom learning but the excitement here means arousing interest, full engagement as well as creating meaning, understanding (mastery over learned material) and student's happy grades.

The goal of fun learning alone is to fully awaken the learning abilities of learners, to make learning fun and rewarding for them, and to contribute wholly to their happiness, intelligence, competence, and success as human beings. Implementation of Joyful learning in Insan Mulia School of Nature in art and culture education is very good. The students in their learning are able to understand about art and culture such as playing gamelan, singing, drawing. Students learn without pressure and enjoy every process that exists. Until it's time for students to show their skills in art learning in race events or other school events.

Insan Mulia Nature School has a school concept that is not burdensome. The Insan Mulia School of Nature is designed as a school that does not burden students. A school that makes the child so cheerful when learning. They feel happy and feel at home in their school. Therefore, in general, the practice of education using three concepts pemajarang namely integrated learning, joyful learning, and cooperative learning.

Each of the art and cultural learning activities is very memorable for the students of Sekolah Alam Insan Mulia. Because in their learning with joyfullearning method they can express their artistic ability with their own skill. Students and learners are relaxed and fun, but still in good education. In order for students to digest the art and culture lessons, it will require preparation in art and culture learning, such as taking students out of passive mentality, removing learning barriers, stimulating interest and curious students, giving students positive feelings about, and relationships which is meaningful to the topic of learning, makes the active students who are moved to think, learn, create and grow.

Because the learning method of joyful learning can motivate the growth of positive self-esteem to children and provide the right environment and conditions for all children. In other words, all children feel that: Their smallest contribution is appreciated, they feel secure (physical and psychic) in the learning environment, and their ideas are respected.

In learning joyful learning, learning media is very important role in shaping the independence of students thinking and acting. Media is one of the important factors in the learning process. Motivation to learn will increase if the learning process conditions are fun, effective and more alive. Thus, good media is required to process learning about learning Islamic Religious Education. Finnuchiaro says that: "Various media such as the picture file, the pocket card, flash cards or words cards, the flannel board or magnetic board, real objects, andmany miscellanous materials" ie: There are many media such as pictures, fast cards or word cards, magnetic board, real objects and lots of different materials. “

Students can learn from their environment, both physical and social environment (contextual teaching and learning). They also rejoice in learning because they start from something they already have, so that confidence arises and it will create a feeling of acknowledgment and appreciation that pleases him because he is given the opportunity to express himself (the theory of constructivism) according to the characteristics of physiological development and psychological. This in turn will motivate them to be actively involved in the learning process because of the academic atmosphere that fits the interests it creates.

Arts and art lessons can serve to foster insight, knowledge, sensitivity, concern, and enhance students' respect and respect for other cultural arts. Specifically serves to develop students' ability to appreciate, create, express, and interact through the arts. With such function expected students can reflect into life and life.

\section{ICT-based Application (Information and Com- munication Technology) at Alam Insan Mulia Surabaya School in art education.}

At this time The development of information and communication technology (ICT) or better known as information technology and technology (ICT) has a tremendous role in the field of education. But not only play in the world of education alone, in the field of industry and business and banking requires ICT to facilitate the running of the company's operations every day. Software such as Microsoft Office or Open Office makes it easy for students to do tasks, such as lab reports and articles, as well as presenting classroom assignments. In addition to facilitate the students in doing the task of ICT also plays an important role to help teachers in preparing and organizing materials that will be submitted to their students so that the process of learning to teach looks more inter- 
esting and fun.

The use of technology in schools cant be avoided apart from the progress of the time that requires schools to innovate, also because of the great responsibility to the community. These responsibilities include helping to prepare learners to become members of a community with academic and professional skills who can apply, develop and create science, technology and art as well as develop and disseminate science, technology and the arts as well as strive for use to improve people's lives and enriching the national culture. But the condition of the school often gets the spotlight and sharp criticism and is labeled as a boring, irrelevant place. School is considered arrogant, ignoring students' ability to learn.

Information communication technology (ICT) is a technology that combines computers with high speed communication lines that carry data, voice and video. (William \& Sawyer: 2003). In the sense above there are two main components in information technology, namely computer technology and communication technology.

Using technology in the learning process has advantages, which simplify and accelerate the work of students (efficient), also fun because students interact with colors, pictures, sounds, video, and something instant. This pleasant situation and condition is actually a very important and essential factor to achieve learning effectiveness. Here technology is able to evoke positive emotions in the learning process.

At Alam Insan Mulia school Implementation of ICT in learning one of them is the use of learning media that can improve the quality of students' abilities. For optimal results learning should be fun and stimulate the imagination and creativity of students. The use of multi-method and multi-media is very helpful to improve learning outcomes. Information technology with audio-visual technology produces new features that can be utilized in education. Multimedia-based learning (technologies involving text, images, sound and video) can present more interesting, non-monotonous subject matter, and facilitate submission.

Some of the advantages of using ICT-based learning in elementary schools are the positive impacts of ICT-based learning, such as: creating fun and exciting learning conditions (emotional effects), students will become more active in the learning process, equip students' skills to use high technology, encouraging constructivist learning environments, encouraging the birth of a creative and self-sufficient self in students to enhance students' critical thinking skills, helping students with slow learning speeds
In addition to having advantages, the application of ICT also has several disadvantages, namely: the application requires a relatively large cost, vulnerable to abuse of function, teachers in the application of ICT demanded to have high expertise, difficult to apply in less developed schools that are generally found in rural areas.

Alam Insan Mulia School honed the skills, processed the information and communicated it. The Insan Mulia School of Nature is not tempted to cram much lesson material for the students. In this school the child is invited to learn to capture the information and then process it with two or more schemata, becoming useful for his practical needs. The ability to synthesize two schemata and cultivate it is urgent. Not much benefit can be taken if a child is given a stack of knowledge if he or she is not trained to look for links or synthesize them. The child is no more than just a "walking dictionary", knowing the definition of abstract formulas. In addition to the ability to process information, students of Alam Insan Mulia School are equipped with the ability to convey the information received through the refraction of presentation and public speaking. Students are given public speaking training.

\section{CONCLUSION}

The introduction of learning joyful learning method is important for the development of children in the learning process. Because joyful leaning is done without burdening the students and the advantages of joyful learning, the knowledge of the children in learning becomes easier to learn because they do the learning with pleasure and no burden. While ICT in elementary school in Sekolah Alam Insan Mulia is also very important because with the development of the era students are required to be creative, innovative and know all the information that can be accepted through ICT-based learning media. Primary school educators are also required to know and develop learning for students. The introduction of ICT for primary school level is still relatively low.

Utilization of ICT is very important to improve the quality of learning and education in primary schools. The things that need to be done in the framework of ICT utilization are by providing ICT facilities and facilities for students and teachers that enable them to access information, encouraging key players in the school system to perform their new roles. ICT-based learning does not always always have advantages but also lacks in its application. Some of the factors that affect the application of ICT learning in elementary school are the ability of the school, the ability of human resources and social environment. 


\section{REFERENCES}

Sanjaya, Wina. 2008. Kurikulum dan Pembelajaran Teori dan Praktik Pengembangan Kurikulum Satuan Pendidikan (KTSP): Kencana.

Jazuli, M. 2008. Paradigma Kontekstual Pendidikan Seni: Unesa University Press.

Sadiman, Arif dkk. 2003. Media Pendidikan Pengertian, Pengembangan dan Pemanfaatannya: Pustekkom Dikbud dan PT. RajaGrafindo Persada.

Ihsan, Fuad. 2008. Dasar-Dasar Kependidikan: Rineka Cipta.

Arsyad, Azhar. 2005. Media Pembelajaran: PT. RajaGrafindo Persada.

Daryanto. 2010. Media Pembelajaran Peranannya Sangat Penting Dalam Mencapai Tujuan Pembelajaran: Gava Media.

Freire, Paulo. 2000. Pedagogy of the Oppressed: The Continuum International Publishing Group Inc. https://cakheppy.wordpress.com/2011/04/09/strategi-joyfull-learning-belajar-menyenangkan/

Andreas Kosasih, "Pembelajaran Yang Menyenangkan (Joyful Learning) Merupakan Alternatif upaya peningkatan mutu pembelajaran", dalam http://stkipwidyayuwana.blogspot.com/,

http://al-alauddin.blogspot.co.id/2012/05/manajemen-lingkungan-pembelajaran.html

http://ti-kelompok16.blogspot.co.id/2011/06/penerapan-pembelajaran-berbasis-ict-di.html 